\title{
RESTORATION PRACTICES USED ON POST MINING SITES AND INDUSTRIAL DEPOSITS IN THE CZECH REPUBLIC WITH AN EXAMPLE OF NATURAL RESTORATION OF GRANODIORITE QUARRIES AND SPOIL HEAPS
}

\author{
TOMÁŠ CHUMAN
}

Department of Physical Geography and Geoecology, Faculty of Science, Charles University in Prague; Albertov 6, CZ-128 43 Prague

Received: $7^{\text {th }}$ April 2015, Accepted: $28^{\text {th }}$ August 2015

\begin{abstract}
Mining of minerals that have significant impact on landscape and landscape functions affects $1 \%$ of the land surface worldwide. In the Czech Republic the extent of mining sites is estimated to be more than $800 \mathrm{~km}^{2}$ and according to the state legislation the land affected by mining should be reclaimed. There are several approaches to land restoration, which are shortly reviewed in this article, from pure technical approach to one adopting natural processes. The review shows increasing appeal of scientist and conservationist to use natural processes e.g. natural or directed succession as an alternative method of post-mining sites or industrial deposits restoration due to growing evidence of conservational value of such sites in human dominated landscapes. The natural processes used for land restoration are often argued to be slow therefore the rate of spontaneous vegetation succession was assessed in stone quarries and on spoil heaps using a sequence of panchromatic aerial images. The results showed that natural processes act fast and vegetation can reach $100 \%$ cover within 10-15 years in granodiorite quarries and on spoil heaps.
\end{abstract}

Key words: reclamation, restoration, quarry, spoil heaps, granodiorite quarry, aerial image, vegetation succession, Skuteč

\section{INTRODUCTION}

Mining of energy, industrial or construction minerals and consequent industrial deposits from minerals processing and utilization that inevitably accompany industrial society have significant impact on landscape and landscape functions. The impact of mining on relief and landscape character is particularly substantial, as could be documented on earth material transfer. Annual deliberate shift of material through mineral extraction is estimated to be around 57,000 Mt (megatons) globally, more than three times higher than annual transport of sediment to the oceans by rivers $(22,000 \mathrm{Mt}$ ) (Douglas \& Lawson, 2001). It is estimated that sites of mineral extraction already cover $1 \%$ of the land surface (Walker \& del Moral, 2003). In the Czech Republic the extent of mining sites is estimated to be $861 \mathrm{~km}^{2}$ (Mineral commodity summaries of the Czech Republic 2013) but this number does not contain a lot of old abandoned stone or sand quarries or extensive industrial deposits e.g. ore/ash-slag that are the results of minerals processing and utilization. Mining causes irreversible modification 
Chuman T.: Restoration practices used on post mining sites and industrial deposits in the Czech Republic with an example of natural restoration of granodiorite quarries and spoil heaps

of relief, removes vegetation, soil cover, and leads to immediate or gradual loss of biotopes. On the other hand, mining often creates new sites in the landscape e.g. water bodies, rock walls, screes, rock ledges, etages or exposed bedrock. These sites are often unique and contrasting with surrounding agroforestal landscape.

According to the state legislation, the land affected by mining should be reclaimed. The history of land reclamation is very old in the Czech Republic as first attempts to oblige land restoration altered by mining was imposed by the General Mining law passed by the Imperial Charter already in 1854 (The State Mining Administration, 2015); however, until the end of second world war the reclamation was carried out as a compensation (Vrbová \& Štýs, 2008). In the 1950's opencast mining affecting vast areas initiated creation of new legislation and in the 1957 the Mining Act was imposed. According to it, a definite obligation to restore land affected by mining was prescribed. A systematic development of reclamation works started in the 50's (Řehoř \& Ondráček, 2009). The mining organizations had to develop a plan for liquidation of damages caused by mining and ensure reclamation of all areas affected by mining. Hence traditional approach to restoration was considered to be the restoration (reclamation) of production, whether agricultural or forestry, it is a written obligation in the current legislation Act on Protection and Utilization of Mineral Resources (No. 44/1988). The plan for rehabilitation and reclamation after termination of mining has to be assessed and authorized by The State Mining Administration. During mining the organization which was granted a permission to mine is obliged to generate sufficient financial reserves to carry out rehabilitation and reclamation after the cessation of mining.

\section{Technical reclamation versus restoration adopting natural processes}

Technical reclamation is generally planned to reach four targets: forest land, agricultural land (arable land, meadows, other e.g. limited extent of vineyards, orchards), create new artificial lakes (hydric reclamation) or other use of land (sport, recreational and leisure facilities, parks) and is the only approach recognised by the law. Technical reclamation usually involves (i) reduction of topographic heterogeneity by remodelling the surface by heavy machinery, including hydro technical engineering works, or fulfilling the space by residual waste, in case of stone quarries, and the (ii) addition of topsoil, important nutrients and (iii) sowing (regularly trefoil-grass mixture) or planting of trees. This technical approach, mechanically applied to any site has unfortunately taken until recently in majority of reclamation plans. The extent of such reclamation works is substantial, often resulting in creation of completely new landscapes. In the Czech Republic in 2012 there were more than 5,000 ha of reclaimed land or land under the reclamation process (Table 1, Mineral commodity summaries of the Czech Republic, 2013). Technical reclamation has been the dominant approach not only in the Czech Republic but also in the neighbouring countries e.g. in Germany (Schulz \& Wiegleb, 2000), or Poland (Kasztelewicz, 2014).

Table 1: State of land reclamation in the Czech Republic prior to 2012

\begin{tabular}{|lllll|}
\hline & agricultural & forestry & hydric & other \\
\hline Land under reclamation (ha) & 1,560 & 5,657 & 577 & 1,722 \\
\hline Reclamation finished (ha) & 6,841 & 9,232 & 2,329 & 3,280 \\
\hline Total (ha) & 8,401 & 14,889 & 2,906 & 5,002 \\
\hline $\begin{array}{l}\text { Percentage of total reclaimed } \\
\text { land (\%) }\end{array}$ & 26.9 & 47.7 & 9.3 & 16.0 \\
\hline
\end{tabular}

(Source of data: Mineral commodity summaries of the Czech Republic, 2013) 
It has been repeatedly pointed out that technical reclamation is on most sites unnecessary because spontaneous vegetation succession acts fast and meanwhile the spoil heaps are left to stabilize before technical reclamation or mining / quarrying has shifted to a new etage or another part of mine / quarry, the process of natural succession immediately starts and vegetation cover is developing.

Thus, the rate of vegetation cover development, which is often argued to be slow in case of spontaneous succession, is comparable to technical reclamation. Moreover the spontaneously developed vegetation forms a diverse mosaic of successional stages with high diversity of species and often with the presence of many endangered plant and animal species e.g. (repeatedly recorded in quarries - plants: Cornus mas, Centaurium erythraea, Epipactis palustris, Vulpia myuros, Dactylorhiza majalis, Pyrola minor, Thymus praecox; butterflies: Hipparchia semele, Pyrgus armoricanus, Proserpinus proserpina). Topographic heterogeneity also leads to creation of water bodies supporting many amphibians (Bufo bufo, Bombina bombina, Pelobates fuscus, Triturus cristatus, Epidalea calamita, Rana dalmatina) and water invertebrates (Anax parthenope, Leucorrhinia rubicunda). Subsequent technical reclamation, which starts after abandoned mining site stabilization, destroys this heterogeneity and surface is covered with topsoil or organic material like milled timber or bark and then sowed or planted. With topsoil, propagules of strong competitors are often introduced (Prach \& Pryšek, 1994). Moreover, topsoil is often rich in eutrophicating nutrinets (nitrogen and phosphorus). Rebele (2015) showed that on the nutrient-rich substrate dense cover of few ruderal species prevent establishment of week competitors but also of woody species, thus, soil fertility is an important driver of plant diversity and structure and dynamics, favouring strong plant competitors, such as ruderal species Calamagrostis epigejos or Artemisia vulgaris. Another often emphasized negative aspect of technical reclamation is the usage of non-native plants for planting, out of which some are regarded as invasive species representing a serious threat to native vegetation (Hodačová \& Prach, 2003). Last but not least, it has also been argued that technical reclamation is very expensive (Tropek \& Prach, 2012).

Restoration of post mining sites and industrial deposits, where natural processes take place instead of technical reclamation, was recognized by a number of studies (Tropek \& Konvička, 2008; Toropek et al. 2012; van Swaay, 2002) to be remarkably valuable for biodiversity conservation in a human dominated landscape where traditional land use practices (e.g. grazing, hay making) are being abandoned, agricultural methods intensified, less productive land formerly used for hay making forested and landscape eutrophicated, as it is the case in the Czech Republic. The above mentioned land use and land cover changes as well as land use practices changes are particularly substantial in the Czech Republic as revealed in several studies (Jačková, Chuman \& Romportl, 2011; Chuman \& Romportl, 2010; Romportl, Chuman \& Lipský, 2013) causing landscape fragmentation and loss of specific biotopes. The species of disappearing biotopes find refuge in abandoned mining sites (Tropek \& Konvička, 2008; Toropek et al., 2012). Especially valuable are biotopes with a mosaic of vegetation in various succession stages, oligotrophic water and terrestrial biotopes or biotopes with exposed fresh bedrock where a specific chemical composition is not diminished by years of pedological processes.

High conservation value is particularly true for limestone quarries in Central Europe, because they host the most endangered species rich habitats e.g. calcareous grasslands (Novák \& Prach, 2003; Tropek et al., 2010). Other types of quarries, mines or industrial deposits are highly valuable for spiders, insect (wasps, beetles, butterflies), plants, birds, amphibians or bats (Řehounková et al., 2011). The authors summarizing the restoration practices and the biological monitoring and research of post mining sites in the Czech 
Chuman T.: Restoration practices used on post mining sites and industrial deposits in the Czech Republic with an example of natural restoration of granodiorite quarries and spoil heaps

Republic state, that for some species in the Czech Republic e.g. (Tawny pipit - Anthus campestris; Grayling - Hipparchia semele or Antlions - genus Myrmeleon) just to name

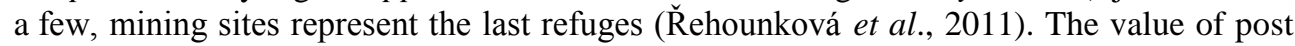
mining sites could be not only biological (presence of endangered species), but also geological, as a demonstration of geological phenomena (e.g. palaeontology, stratigraphy, mineralogy). For both reasons, high numbers of such sites were declared protected areas in the Czech Republic (Chuman, 2010).

\section{Natural processes in restoration}

Number of studies of spontaneously restored mining sites and industrial deposits have proven that majority of such sites have the potential to be restored spontaneously by natural processes e.g. in the Czech Republic on spoil heaps (Prach \& Pyšek, 1994; Tropek \& Prach, 2012; Prach, 1987; Frouz et al., 2008), stone quarries (Beneš et al., 2003; Chuman, 2006; Tichý, 2006; Tropek et al., 2010; Novák \& Prach, 2003; Tropek \& Konvička, 2008; Trnková et al., 2010), sandpits (Řehounková \& Prach, 2006; 2008) peat quarries (Konvalinková \& Prach, 2010) and manmade deposits e.g. ore/ash-slag deposits (Kováŕ et al., 2004) but also elsewhere in Europe e.g. on coal spoil heaps in Germany (Schulz \& Wiegleb, 2000; Wiegleb $\&$ Felinks, 2001) or the Ubited Kingdom (Bradshaw, 1997).

Although the first studies were published in the Czech Republic already in the late 70's and in 80's describing vegetation succession on sedimentation pond after pyrite processing (Kováŕ, 1979; 1982), on sites created by open-cast brown coal mining (Prach, 1982; 1987) or focusing on vegetation succession in limestone quarries (Sádlo, 1983) the technical approach is still the dominant one and the willingness of mining and reclamation companies to adopt new approaches is limited. The restoration of mined land using natural processes described in the above cited studies is not meant to entirely replace technical reclamation but to be an alternative. Prach and Hobs (2008) suggest that there can be a continuum between purely technical reclamation and spontaneous succession. In some cases the spontaneous succession would not lead to desired result and the course of vegetation development is necessary to manipulate to a desired target state. This might be the case when alien or ruderal species invade the post-mining site from the surroundings. The surrounding vegetation plays a critical role in the success of spontaneous succession because the establishment of a given plant species in a post mining site depends on the species pool (Zobel et al., 1998). Other factors influencing establishment of plant species are dispersability of propagules of a certain species (Finegan \& Harvy, 1981) and tolerance of the developing individuals to the abiotic and biotic conditions (Bradshaw, 1983). Many studies showed that the landscape composition, and therefore the potential species pool in the surroundings plays important role, however these studies differ in the radius referred to as the surrounding. Rehounková and Prach (2006) showed that out of land cover categories the proportion of arable land within $1 \mathrm{~km}$ distance explained the highest proportion of variance in species composition. On the other hand, Novák and Prach (2003) showed that the presence of natural xerotherm grasslands in the vicinity of a quarry (up to $30 \mathrm{~m}$ from the margin of a quarry) had a significant effect on the course of succession. Borgegård (1990) also proved the surrounding vegetation, recorded in 50-100 m buffer, to influence the species composition. Kirmer et al. (2008) showed that the occurrence of species up to a distance of at least $17 \mathrm{~km}$ plays an important role in colonization processes following largescale destruction of ecosystems; however, in the woodland and grassland dominated landscape almost $89 \%$ of species present at the mined sites occur within $3 \mathrm{~km}$ distance. On sites dominated by arable land only $65 \%$ of species present at the mined sites occur within $3 \mathrm{~km}$ distance. Thus only $11 \%$ and $36 \%$ of species occurred farther than $3 \mathrm{~km}$ away (Kirmer et al., 2008). There are 
several species (e.g. orchids) colonizing the sites from large distance however the majority of species comes from the surrounding landscape. Ash et al. (1994), as well as Bradshaw (1983), likewise observed that species with very small seeds and specialized soil preferences bridge distances up to $40 \mathrm{~km}$ to reach suitable sites. Thus, the surrounding vegetation should be considered and alien plants such as in the Czech Republic Robinia pseudoacacia or Pinus nigra should be eradicated or controlled. On the other hand, desired species composition or acceleration of natural succession might be supported by application of hay with grass seeds, sowing of seeds of local origin or planting trees and shrubs as successfully done on several sites by Novák \& Prach (2010), Tichý (2012) and Tichý \& Donocik (2012), Kovář et al. (2012). In some cases the manipulation and direction of natural processes might be targeted to maintain the vegetation in a specific seral stage to support specific species composition or to maintain food source for specific species, therefore disturbance management is necessary. There are many approaches to restoration of post mining sites and industrial deposits from purely natural succession through directed succession to active management practices. It always depends on the restoration target. Technical reclamation should be used only in specific cases such as in sites that are under risk of water and wind erosion, acid rock drainage, landslides, mass wasting, risk of water contamination.

Technical measures might be used to ameliorate extreme site conditions such as extreme dryness or toxicity e.g. by nutrient poor topsoil application. Otherwise such sites would retard the establishment of vegetation for a long time. The vegetation development might be slower under spontaneous succession than under reclamation especially in stone quarries as succession involves habitats of open rocks were the soil is absent. There are many studies assessing spontaneous succession on post mining sites but these studies mostly focus on species composition and its change during succession. Prach et al. (2014) state that about after 20 years of vegetation succession a mosaic of various vegetation types develops in most post-mining sites, which obviously persists for a relatively long period. Studies on the rate of vegetation cover development in acidic stone quarries are, however, limited. For example study of vegetation succession in granodiorite quarries (Chuman, 2006) showed that in two operating stone quarries of 13 and 15 ha in size the vegetation cover have already expanded to over $40 \%$ and $42 \%$ respectively. This indicates that parts of quarries left undisturbed for some time are quickly vegetated despite the harsh environment but the rate is not satisfactorily known. Therefore, the aim of this study was to assess the rate of vegetation succession in granodiorite quarries and on spoil heaps near the town Skuteč, where there are many quarries close to one another, thus, not differing in the bedrock, climate or species pool. Moreover, the study takes the advantage of using a sequence of archival panchromatic aerial images to record vegetation development since site abandonment.

\section{METHODS}

\section{Study area}

The study was conducted in the proximity of the town Skuteč, area of long quarrying history, located in the central part of the Czech Republic, Central Europe. Quarrying led to a significant change of the landscape in this region as more than $1 \mathrm{~km}^{2}$ out of $36.5 \mathrm{~km}^{2}$ (the extent of study area) was directly affected either by quarrying or deposition of spoil (Chuman, 2006). The average altitude of the study area is $403 \mathrm{~m}$ a.s.l., the mean annual temperature is between $7-8^{\circ} \mathrm{C}$, and the mean annual precipitation is between $600-650 \mathrm{~mm}$ with maximum precipitation in the summer months $(200-250 \mathrm{~mm})$ (Tolasz et al., 2007). The bedrock is formed by granodiorite. The landscape $(36.5 \mathrm{sq} . \mathrm{km})$ is a mosaic of arable land 
Chuman T.: Restoration practices used on post mining sites and industrial deposits in the Czech Republic with an example of natural restoration of granodiorite quarries and spoil heaps

(40\%), managed forests $(31 \%)$, settlements $(4 \%)$, meadows, pastures, orchards $(23.5 \%)$, numerous quarrying sites (1\%) and several water bodies $(0.5 \%)$ (Czech Office for Surveying, Mapping and Cadastre). Forest are represented mostly by spruce plantations localy replaced by mixture of pine forest with birch and oaks, and alder on wet sites.

\section{Data collecting}

The rate of succession was determined using supervised classification of panchromatic aerial images with $0.5 \mathrm{~m}$ resolution and RGB image provided as scanned images by the Military Office for Geography and Hydrometeorology. Images from years 1950, 1956, 1965, 1966, 1968, 1975, 1976, 1978, 1980, 1984, 1986, 1990, 1992, 2002 were first orthorectified using OrthoEngine 9.0 (PCI Geomatica) with a digital terrain model of $10 \mathrm{~m}$ resolution. Ground control points were collected from current orthogonal images (Czech Geodetic Survey).

A regular 10 x 10 meter grid was superimposed over spoil heaps and quarries and the grid cells where mineral surface with no vegetation was detected in any year and where the surface was not disturbed later on, were selected (called study plots hereafter). In selected study plots the land cover was classified using supervised classification approach with a maximum likelihood classifier by the means of Image analysis for ArcGIS into four in the field easily recognized classes: no vegetation, initial vegetation (sparse cover), herbaceous vegetation, woody vegetation. Subsequent classification resulted in a matrix of four land cover classes which showed spectral and textural differences; however, extensive manual corrections were necessary when classifying old panchromatic images, mainly due to the presence of shadows of crowns and shadows casted by quarry walls. Classified raster data were used to determine the extent of each land cover category in selected plots in a particular year.

The accuracy of the land cover data generated by supervised classification and subsequent manual correction was evaluated using generation of 150 control points randomly placed in study plots. Each point was assigned the land cover class based on 2002 aerial image classification and this was compared to field verification in 2004. There was a two year time delay but there was no other independent set of land cover data to use for validation. Based on 150 control points we computed the overall accuracy, producer and useraccuracy.

During the field verification the dominant woody and herbaceous species within the study area were recorded but the detailed description is beyond the scope of this article.

I analysed:

- Whether the rate of succession (number of years the herbaceous and/or woody vegetation reaches 100 percent cover) differ between spoil heaps and quarries

- Whether the plots on spoil heaps and plots in quarries differ in the proportion of woody / herbaceous vegetation in time the vegetation cover reaches 100 percent

- Whether the proportion of land cover classes changes during the succession. This was analysed when using land cover classes and succession age as quantitative variables but also as categorical variables age of succession was categorised to eight categories as follows: less than 2 years, 3-5, 6-10, 11-15, 16-20, 21-25, 26-30 and above 30 years. Land cover classes were expresses as presence/absence of categories of following proportions: $0-5 \%, 5-25 \%, 25-50 \%, 50-75 \%, 75-100 \%$. 
Analysis of variance was conducted to assess the difference between spoil heaps and quarries in the rate of succession and the proportion of the woody / herbaceous vegetation by means of Statistica 6 software. Redundancy analysis (RDA) was conducted to assess the influence of successional age on the proportion of land cover classes. Multivariate analyses were performed using CANOCO for Win 4.5 (Microcomputer Power, Ithaca, NY). The results were visualized by the means of CanoDraw.

The analysis of classified aerial images showed that there were rather low numbers of $10 \times 10 \mathrm{~m}$ grid cells where mineral surface where no vegetation was detected in any year and where the surface was not disturbed later on. Moreover, it was not possible to apply random selection of these grid cells as only 152 cells met the criteria and they were often located close to each other or were true neighbours (Fig. 1). Neighbouring plots could undergo very similar rate of succession, as site conditions are very likely to be similar and the neighbouring already vegetated squares become a source of propagules, therefore I first tested whether the rate of succession on selected plots depends on the proximity of established vegetation cover in the surroundings. I measured the shortest distance between each selected plot covered by bare ground to the established vegetation. Then I tested whether the number of years the selected plots reached 100 percent vegetation cover depends on the distance to the established vegetation. This was not significant (mean 19 meters; std $14 \mathrm{~m}$ ). Thus, I treated neighbouring plots as independent and carried out the analysis of vegetation succession.

Table 2: Classification accuracy based on 150 control points showing the overall accuracy, producer and user accuracy

\begin{tabular}{|c|c|c|c|c|c|c|c|}
\hline \multirow{8}{*}{ 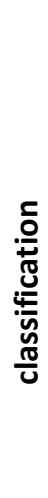 } & & \multicolumn{6}{|c|}{ field validation } \\
\hline & & $\begin{array}{l}\text { woody } \\
\text { veg. }\end{array}$ & $\begin{array}{l}\text { herbaceous } \\
\text { veg. }\end{array}$ & $\begin{array}{l}\text { initial } \\
\text { veg. }\end{array}$ & no veg. & $\begin{array}{l}\text { row } \\
\text { total }\end{array}$ & $\begin{array}{l}\text { Useraccur } \\
\text { acy }\end{array}$ \\
\hline & woody veg. & 60 & 5 & 0 & 0 & 65 & 0.92 \\
\hline & herbaceous veg. & 4 & 50 & 3 & 0 & 57 & 0.88 \\
\hline & initial veg. & 0 & 4 & 9 & 2 & 15 & 0.60 \\
\hline & no vegetation & 0 & 0 & 5 & 8 & 13 & 0.62 \\
\hline & column total & 64 & 59 & 17 & 10 & 150 & \\
\hline & Produceraccuracy & 0.94 & 0.85 & 0.53 & 0.80 & & 0.85 \\
\hline
\end{tabular}

The overall accuracy of classification of 2002 aerial image was $85 \%$. The user and producer accuracy indicates that the classification of woody vegetation and herbaceous vegetation was fairly good, the classification of "no vegetation" and "initial vegetation" was only limited and the discrimination of these two land cover classes was sometimes incorrect. However, as could be seen from Table 2 the misclassification error could be assigned to time delay. Misclassified initial vegetation or no vegetation class developed towards herb or initial vegetation. 
Chuman T.: Restoration practices used on post mining sites and industrial deposits in the Czech Republic with an example of natural restoration of granodiorite quarries and spoil heaps

Fig. 1: An example of location of selected and analysed $10 \times 10 \mathrm{~m}$ grid cells in a quarry (on the right) and on a spoil heap (on the left) with classified land cover classes in the year 1978

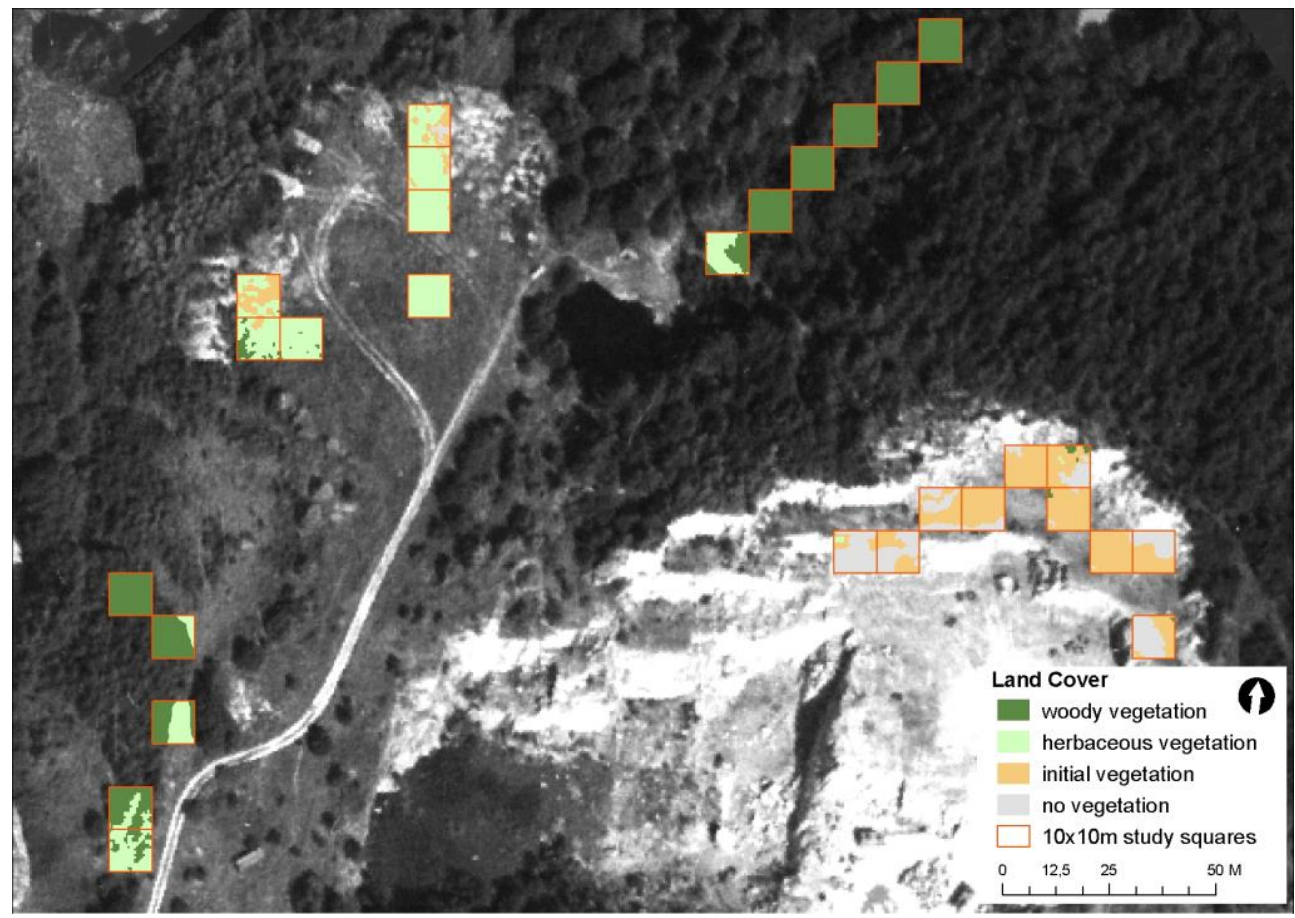

\section{RESULTS}

Out of 152 study plots in 132 plots vegetation cover reached 100 percent. The maximum age of succession series captured by analysis of aerial images in quarries was 52 years. On spoil heaps the maximum succession series was 16 years shorter, lasting only 36 years. There were 20 plots, out of which 3 were located in quarries and 17 located on spoil heaps, where the vegetation did not reach 100 percent cover. In all three plots located in quarries succession series lasted 26 years. 17 plots located on spoil heaps not reaching 100 percent vegetation cover were 2, 8 and 10 years old. Out of these, 17 plots 4 plots were only 2 years old and have the potential to reach complete vegetation cover to the age of 8 years which is the median number of years the vegetation cover reaches 100 percent on spoil heaps.

The analysis of the different rate when the vegetation reaches 100 percent cover between spoil heaps and quarries (number of years the herbaceous and/or woody vegetation reaches 100 percent cover) showed significant difference between spoil heaps and quarries $(\mathrm{P}<<0.05$, Kruskal/Wallis ANOVA test). 20 plots, where the vegetation did not reach 100 percent cover were not included in the analysis. The median number of years the vegetation reaches 100 percent cover is 15 (mean $=12.4$, std. 0.7 ) years for quarries and 8 (mean=9.3; std. 0.6) years for spoil heaps. The analysis shows that plots on spoil heaps become overgrown faster than plots in quarries and during this time, plots on spoil heaps show higher proportion of herbal vegetation than plots in quarries ( $\mathrm{P}<<0.05$, Kruskal/Wallis ANOVA test). Plots in quarries show rather equal proportion of herbal and woody vegetation at the time vegetation 
reaches 100 percent cover. On plots in quarries the median herbal vegetation cover reaches $59 \%$ and woody vegetation $41 \%$. On plots on spoil heaps the herbal vegetation entirely dominate covering $89 \%$. The woody vegetation covers only $11 \%$.

The direct gradient redundancy analysis (RDA) of the influence of succession age on land cover composition showed significant results for both quarries and spoil heaps. I analysed separately plots on spoil heaps and in quarries. Succession age explains $21 \%$ of variability in land cover composition of plots on spoil heaps and $17 \%$ in quarries. Both types of plots show strong positive correlation of "woody vegetation" with succession age (Fig. 2 and 3). Land cover categories "no vegetation" and "initial vegetation" both show negative correlation with succession age (Fig. 2 and 3). On the other hand, "herbal vegetation" shows rather indifferent relation to succession age indicating that herbal vegetation is present in young as well as in old succession stages (Fig. 2 and 3). The most frequent spontaneously established woody species recorded in quarries and on spoil heaps were Salix caprea, Betula pendula, Populus tremula, Alnus glutinosa and Pinus sylvestris, in quarries frequently also Cytisus scoparius, Rosa sp. and Rubus sp.. Herbaceous species recorded in quarries and on spoil heaps were mainly Calamagrostis epigejos, Arrhenatherum elatius, Urtica dioica, Impatiens parviflora and Poa nemoralis.

Fig. 2: RDA analysis of land cover classes change during the succession in studied quarries. The succession age explains $17 \%$ of variability in land cover data. $(P=0.002)$

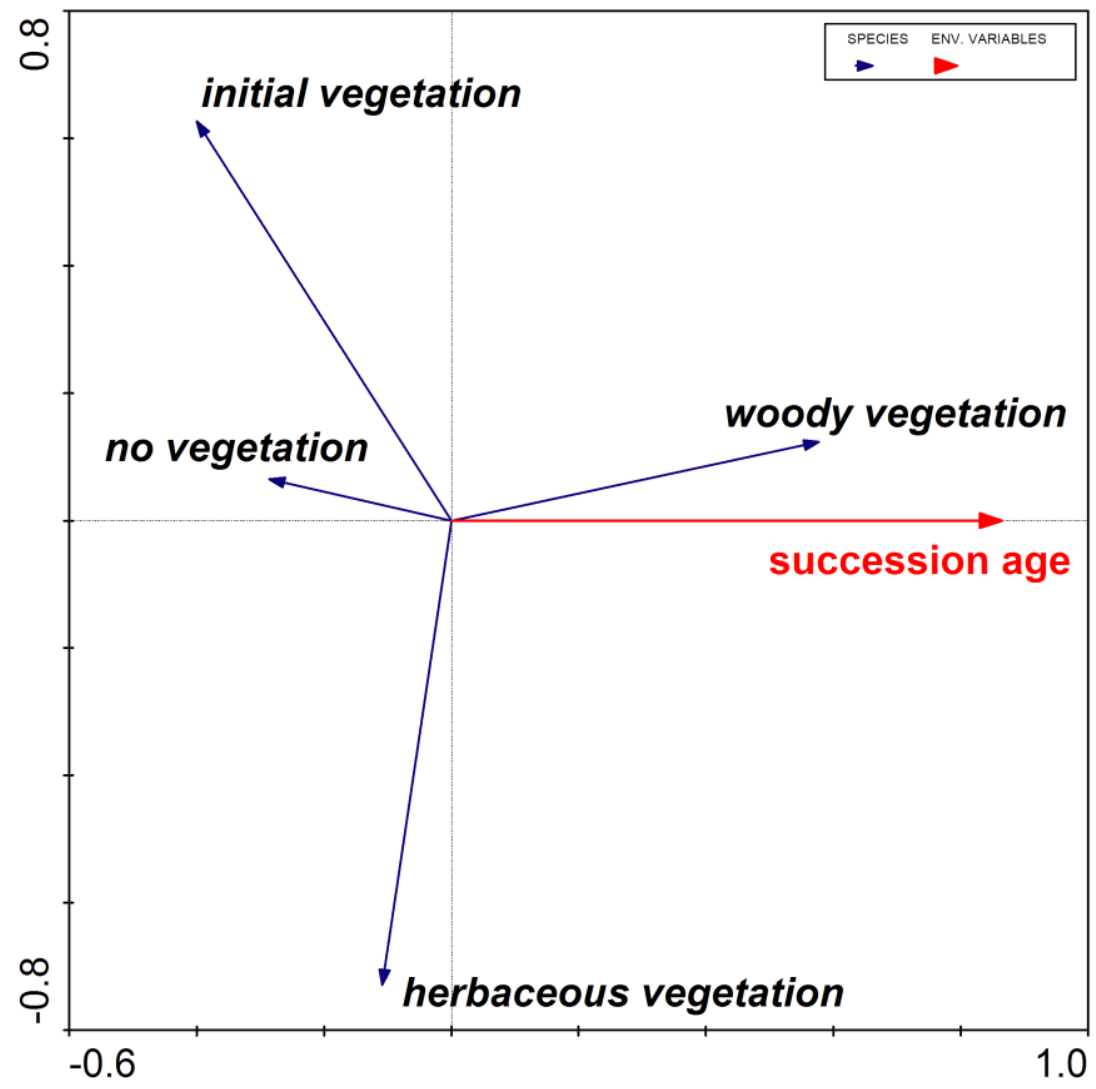


Chuman T.: Restoration practices used on post mining sites and industrial deposits in the Czech Republic with an example of natural restoration of granodiorite quarries and spoil heaps

Fig. 3: RDA analysis of land cover classes change during the succession in studied plots on spoil heaps. The succession age explains $21 \%$ of variability in land cover data. $(\mathbf{P}=\mathbf{0 . 0 0 2})$

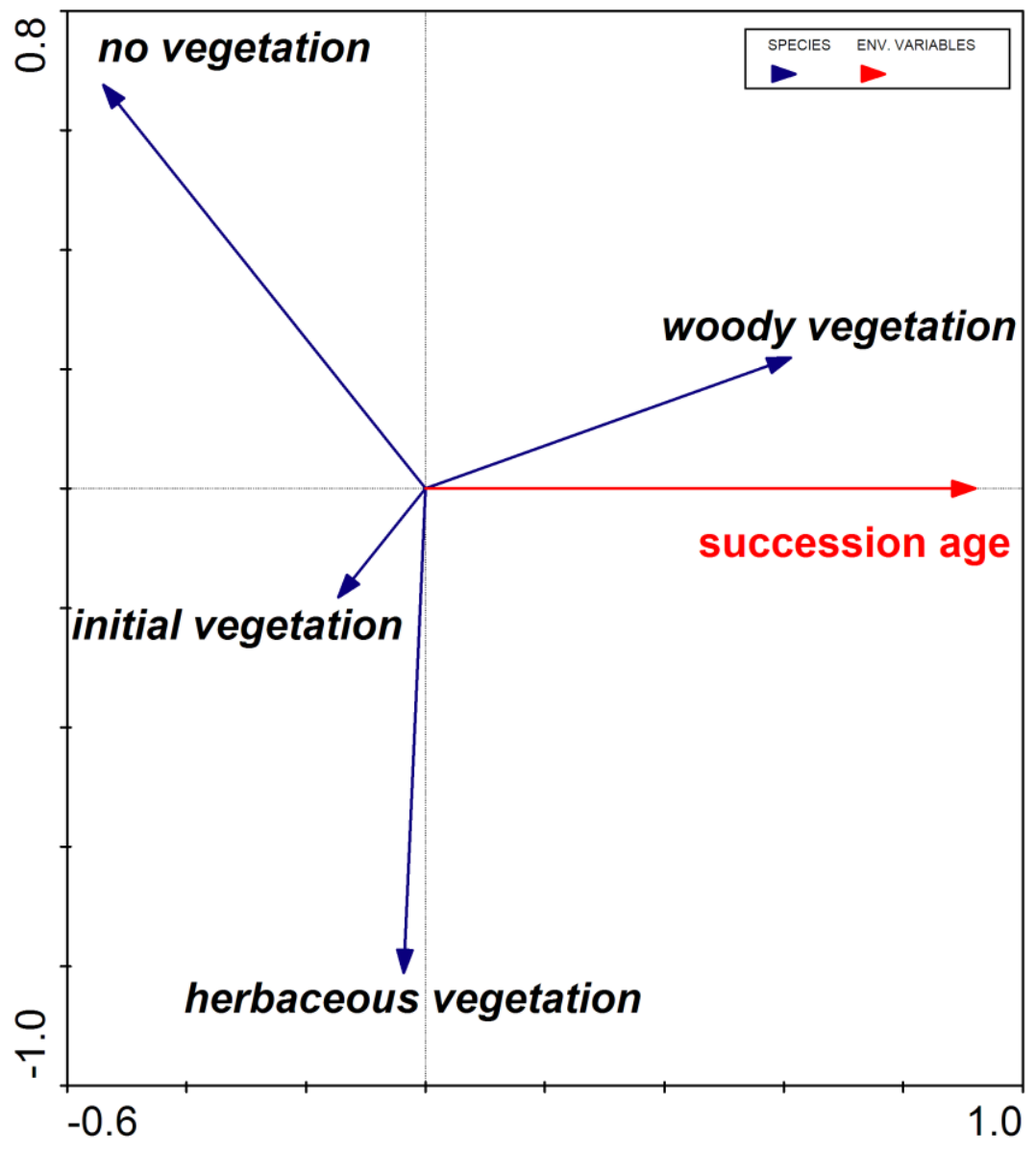

The analysis of the relationship between land cover and succession age when both expressed as categorical data yielded complementary view on the direction of changes in land cover classes after certain time (Fig. 4 and 5). The presence of land cover classes was significantly influenced by succession age for both quarries and spoil heaps but the explained variability decreased to $12.1 \%$ for plots in quarries and to $16.4 \%$ for plots on spoil heaps. The ordination diagrams revealed main difference between plots on spoil heaps and in quarries in the rate of land cover change. Whereas on spoil heaps the most dynamic land cover changes occur within first 15 years in quarries the dynamic equilibrium is reached five years later. 
Fig. 4: RDA analysis of land cover classes expressed as presence/absence of categories covering particular percentage of a square in a quarry. (no veg. - no vegetation, ini. veg. - initial vegetation, herb. veg. - herbaceous vegetation, woody veg. - woody vegetation) percentage categories 0_5 - up to 5\%, 5_25 - 5-25\%, 50 - 25-50\%, 75-50-75\%, $100-$ $75-100 \%$.

The categories of succession age explains $12.1 \%$ of variability in presence of categories of land cover $(\mathrm{P}=0.002)$

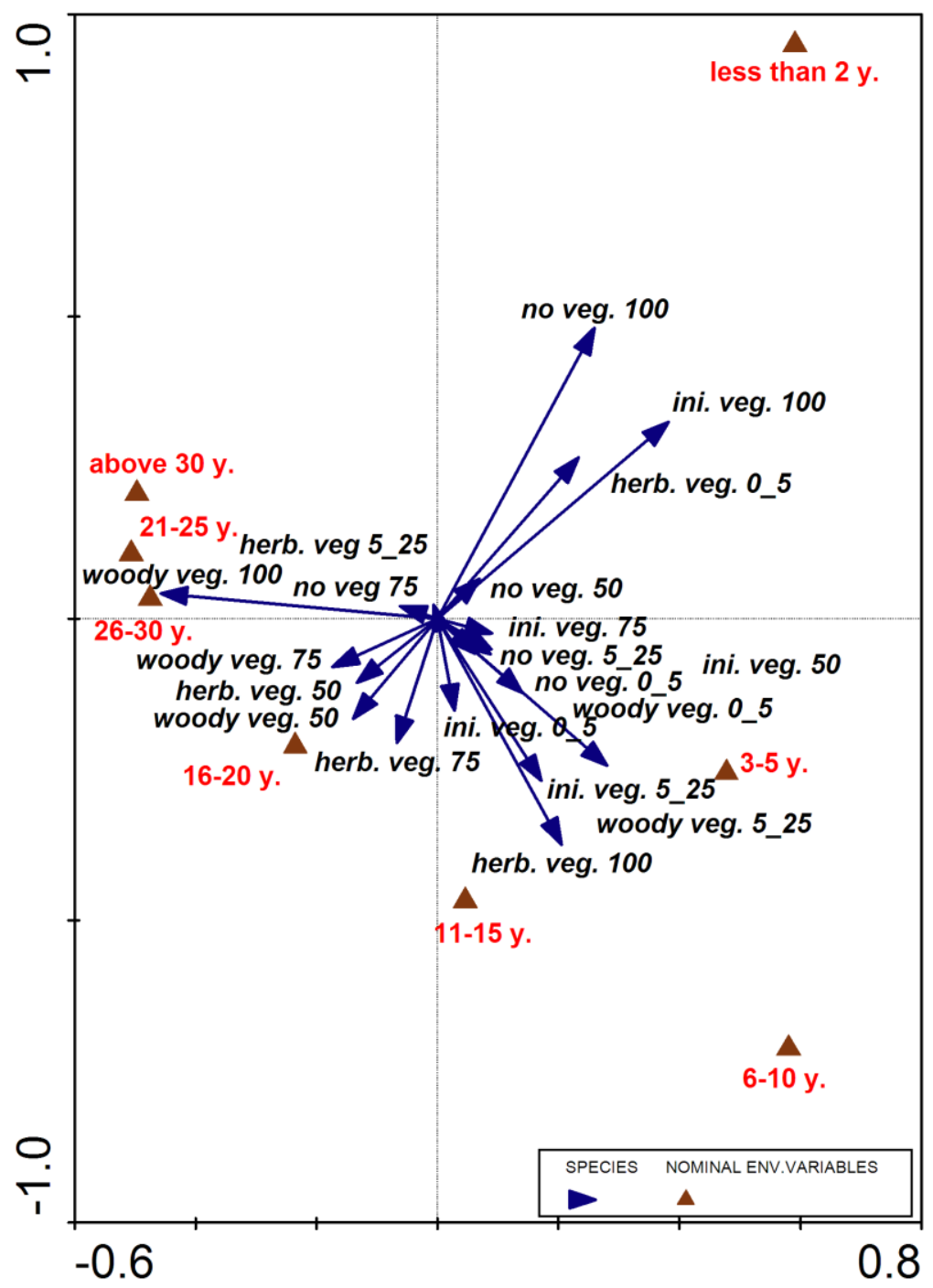


Chuman T.: Restoration practices used on post mining sites and industrial deposits in the Czech Republic with an example of natural restoration of granodiorite quarries and spoil heaps

Fig. 5: RDA analysis of land cover classes expressed as presence/absence of categories covering particular percentage of a square on spoil heaps. (no veg. - no vegetation, ini. veg. - initial vegetation, herb. veg. - herbaceous vegetation, woody veg. - woody vegetation) percentage categories 0_5 - up to 5\%, 5_25-5-25\%, 50 - 25-50\%, $75-50-75 \%, 100-$ 75-100\%.

The categories of succession age explains $16.4 \%$ of variability in presence of categories of land cover $(\mathrm{P}=0.002)$.

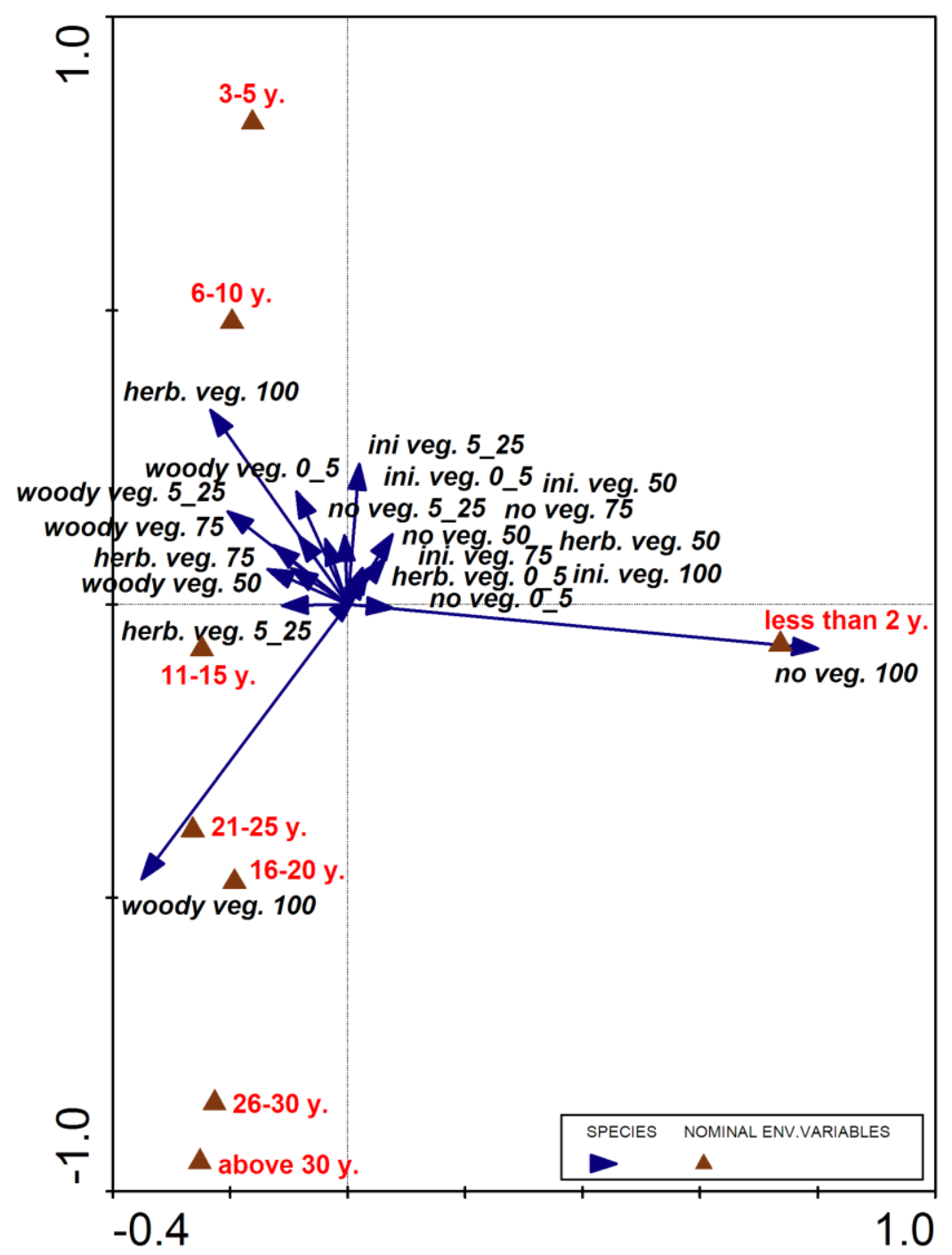




\section{DISCUSSION}

Number of studies has confirmed the effectiveness of remote sensing techniques for different mining applications (Erener, 2011). However, despite rapid development of remote sensing and the availability of such data the use of remote sensing for monitoring vegetation succession in restoration of mined land is not very common. Most studies in the Czech Republic are based on classical vegetation mapping using acquisition of accurate data recorded on standard plots. Nevertheless, there are some examples from abroad. Felinks et al, (1998) studied coal mines, Bonifazi et al, (2003) assessed the success of spontaneous restoration after 24 years of limestone quarries, Koruyan et al. (2012) studied marble quarries. These studies were using satellite data but there are no studies using aerial images. The advantage of aerial images is that there exists archive images from 1940-50s with regular intervals of acquisition, thus, land cover dynamics of past 70 years can be studied. However due to relatively low spectral resolution only coarse vegetation units can be distinguished.

Historical aerial photographs have long been recognized as an important source of information for studies of vegetation succession or vegetation dynamics of forest or shrubs (Callaway \& Davis, 1993; Guariguata, 1990; Kadmon \& Harari-Kramer, 1999; Turner et al., 1996; Treml et al., 2011). However Kadmon and Harari-Kramer (1999) concluded that this approach has two important limitations. First, the data obtained from the aerial images are not objective because it is not based on explicitly defined measurement procedures and second, because the photo interpretation is extremely time consuming, studies of vegetation dynamics based on manual interpretation of aerial photographs either limit the analysis to relatively small plots or focus on relatively coarse vegetation units (Callaway \& Davis, 1993; Guariguata, 1990; Turner et al., 1996). Relatively coarse vegetation units and small plots were delineated in our study as well. The coarse vegetation units do not cover reed and sedge vegetation that occurs in granodiorite stone quarries as shown for example by Trnková et al. (2010), however this type of vegetation was rather rare in the study area. The selected land cover classes were dominant vegetation physiotypes.

The classification performed in this study was based on the texture and spectral information into relatively coarse vegetation units that reflects height of vegetation and vegetation cover. Thus the land cover class "woody vegetation" could include both shrubs and trees. Similarly the land cover class "herbaceous vegetation" could include seedlings of trees within herbaceous vegetation. Nevertheless, the data acquired from classified aerial images provide valuable source of information on vegetation succession of coarse vegetation categories showing the rate and direction of succession.

Vegetation succession develops towards woodland in temperate climate in the Czech Republic at most derelict sites (Prach \& Pyšek, 1994). At post mining sites succession is directed mostly by moisture and soil acidity and nutrient content. Prach and Pyšek (1994) showed in a study from various habitats that woody plants are less successful in colonizing extremely nutrient poor sites, acid sites and both xeric and excessively wet sites. At excessively wet sites succession towards reed or sedge wetlands was described in sandpits or stone quarries for example by Řehounková and Prach (2006) or Trnková et al. (2010). Shrubby or shrubby grassland vegetation usually establish on dry sites with very shallow soil in the most dry regions in the Czech Republic such as in basalt quarries or limestone quarries (Novák \& Prach, 2003; Sádlo \& Tichý, 2002) or on sites with almost no water retention capacity such as on abandoned tailings (Kovár et al., 2011). Extremely nutrient poor sites or acid sites may show very slow vegetation establishment. Some sites after coal mining remain free of vegetation even after 70 years (Wiegleb \& Felinks, 2001). At most postmining sites however, the succession ultimately develops towards woodland (Prach \& Pyšek, 1994; 
Chuman T.: Restoration practices used on post mining sites and industrial deposits in the Czech Republic with an example of natural restoration of granodiorite quarries and spoil heaps

Trnková et al., 2010). The rate of vegetation establishment varies and is mostly driven by site moisture (Wolker \& del Moral, 2003). The overall vegetation cover can increase quickly and reach $50 \%$ or even $90 \%$ cover already after two years of spontaneous succession. $50 \%$ cover was reached on nutrient poor sand and $90 \%$ on sites with topsoil application (Rebele, 2014). The rate of tree establishment, however, varies greatly. Slow rate of succession of trees was documented by Prach (1987) and Hodačová and Prach (2003) in dry regions such as Most region in the Czech Republic with mean annual precipitation between $500-550 \mathrm{~mm}$, where trees had rather low cover even in late successional stages. Hodačová \& Prach (2003) in the study from the Most region showed that spontaneously revegetated plots after 1-5 years had only negligible cover of trees that increased to 1 percent after 6-10 years, restored sites reached $4.5 \%$ cover of trees after 6-10 years. Contrastingly, the rate of tree establishment at sites in gradodiorite quarries and on spoil heaps is very fast. The complete vegetation cover was reached within 8 - 15 years. The rate was faster at spoil heaps presumably because spoil heaps were created not only by the waste rock but also by the overburden, thus these sites were less susceptible to drying and presumably showed better also other soil properties e.g. base saturation, cation exchange capacity etc. On the other hand, Rebele (2013) showed that the rate of succession is not increasing with increasing productivity thus the soil water retention plays presumably the greatest role. The fast succession in the study area could be explained by higher moisture, the mean annual precipitation is between $650-750 \mathrm{~mm}$ (Tolasz et al., 2007) and by intensive input of disapores from the surroundings as most spoil heaps and quarries, where the study 10 x 10 sq. m plots were located, were relatively small (median quarry size was $580 \mathrm{~m}^{2}$ and median spoil heap size was $1560 \mathrm{~m}^{2}$ ). On spoil heaps the most dynamic land cover changes occur within first 15 years in quarries the dynamic equilibrium is reached five years later. On both sites the observed succession ended mostly by woody vegetation, however, on some plots a mosaic of herbaceous, woody and even initial and no vegetation have persisted for a long time. Prach et al. (2001) showed that succession could be blocked for a long time by strong herbaceous competitors such as by dense cover of Calamagrostis epigejos where the establishment of tree seedlings is difficult. The remaining initial vegetation and no vegetation were observed on former quarry etages formed by exposed bedrock or covered by very shallow initial soil. Spontaneous succession proceeded relatively quickly to the (semi-)natural vegetation typical of the area i.e. woodland, but colonization of ground flora typical for that natural woodland is rather slow (Sádlo \& Tichý, 2002). To fasten the colonization woodland topsoil from the surroundings might be used to spread over restored sites. It will include seeds and root material as well as fungal spores and mycelia, and can therefore be an effective means of introducing ground flora. Where available, this can be applied in clumps from which vegetation will spread over time.

\section{CONCLUSION}

The article reviews approaches to land reclamation after mining and quarrying in the Czech Republic, showing the increasing appeal of scientist and conservationist to adopt natural or directed succession as an alternative method of post-mining land restoration, due to growing evidence of the conservational value of post-mining sites and industrial deposits and their potential to restore via natural processes. The presented results of the rate of vegetation succession in abandoned granodiorite quarries supports the idea that most abandoned mining sites have the potential to restore via natural processes and despite the harsh environment the vegetation succession is fast and can reach complete vegetation cover within 10-15 years. However at some extremely dry sites bare ground stage can last more than 20 years in quarries. 


\section{REFERENCES}

Act No. 44/1988 Coll., on the protection and utilization of mineral resources (The Mining Act)

Ash, H.J., Gemmell, R.P. \& Bradshaw, A.D. (1994). The introduction of native plant species on industrial waste heaps: a test of immigration and other factors affecting primary succession. Journal of Applied Ecology, 31: 74-84.

Beneš, J., Kepka, P. \& Konvička, M. (2003). Limestone Quarries as Refuges for European Xerophilous Butterflies. Conservation Biology, 17(4): 1058-1069

Borgegård, S. O. (1990). Vegetation development in abandoned gravel pits: effects of surrounding vegetation, substrate and regionality. Journal of Vegetation Science, 1: 675-682.

Bonifazi, G., Cutaia, L., Massacci, P. \& Roselli, I. (2003). Monitoring of abandoned quarries by remote sensing and in situ surveying. Ecological Modelling, 170: 213-218.

Bradshaw, A. (1983). The reconstruction of ecosystems. Journal of Applied Ecology, 20: $1-17$.

Bradshaw, A. (1997). Restoration of mined lands - using natural processes. Ecological Engineering, 8: 255-269.

Callaway, R.M. \& Davis, F.W. (1993). Vegetation dynamics, fire, and the physical environment in coastal central California, Ecology, 74: 1567-1578.

Douglas, I. \& Lawson, N. (2001). The Human Dimensions of Geomorphological Work in Britain. Journal of Industrial Ecology, 4 (2): 9-33.

Erener, A. (2011). Remote sensing of vegetation health for reclaimed areas of Seyitömer open cast coal mine. International Journal of Coal Geology, 86: 20-26.

Felinks, B., Pilarski, M. \& Wiegleb, G. (1998). Vegetation survey in the former brown coal mining area of eastern Germany by integrating remote sensing and ground-based methods. Applied Vegetation Science, 1: 233-240.

Finegan, B. G. \& Harvey, H. J. (1981). The dynamics of chalk quarry vegetation. In: Davis, B. N. K. (ed.), Ecology of quarries: the importance of natural vegetation (p. 41-46). Institute of Terrestrial Ecology, Cambridge.

Frouz, J., Prach, K., Pižl, V., Háněl, L., Starý, J., Tajovský, K., Materna, J., Balík, V., Kalačík, J. \& Řehounková, K. (2008). Interactions between soil development, vegetation and soil fauna during spontaneous succession in post mining sites. European Journal of Soil Biology, 44:109-121.

Guariguata, M.R. (1990). Landslide Disturbance and Forest Regeneration in the Upper Luquillo Mountains of Puerto Rico. Journal of Ecology. 78 (3): 814-832.

Hodačová, D. \& Prach, K. (2003). Spoil Heaps From Brown Coal Mining: Technical Reclamation Versus Spontaneous Revegetation. Restoration Ecology, 11(3): 385-391.

Chuman T. (2006). Př́íspěvek k poznání přirozené obnovy granodioritových lomů na Skutečsku. [Contribution to knowledge of natural restoration of abandoned granodiorite quarries near the town of Skuteč]. Zprávy České Botanické Společnosti, 41(Mater. 21): 111-115 [in Czech].

Chuman, T. (2010). Abandoned mining sites as objects of nature protection. In.: Řehounková K., Řehounek J. \& Prach K. (eds.). Near-natural restoration vs. technical reclamation of mining sites in the Czech Republic (p. 155-161), University of South Bohemia in České 
Chuman T.: Restoration practices used on post mining sites and industrial deposits in the Czech Republic with an example of natural restoration of granodiorite quarries and spoil heaps

Budějovice, České Budějovice. [in Czech].

Chuman, T., \& Romportl, D. (2010). Multivariate classification analysis of cultural landscapes: An example from the Czech Republic. Landscape and Urban Planning, 98 (3-4): 200-209.

Jačková, K., Chuman, T. \& Romportl, D. (2011). Comparison of land cover changes in protected and unprotected sites on the outskirts of Prague metropolis (the Czech Republic), 1990-2006. Acta Universitatis Carolinae, Geographica, 46 (2): 67-79.

Kadmon, R. \& Harari-Kramer, R. (1999). Studying long-term vegetation dynamics using digital processing of historical aerial photographs. Remote Sensing Environment, 68:164-176.

Kasztelewicz, Z. (2014). Approaches to post-mining land reclamation in Polish open-cast lignite mining. Civil and Environmental Engineering Reports. 12 (1): 55-67.

Kirmer, A., Tischew, S., Ozinga, W. A., von Lampe, M., Baasch, A. \& van Groenendael, J. M. (2008). Importance of regional species pools and functional traits in colonization processes: predicting re-colonization after largescale destruction of ecosystems. Journal of Applied Ecology, 45: 1523-1530.

Konvalinková, P. \& Prach, K. (2010). Spontaneous succession of vegetation in mined peatlands: a multi-site study. Preslia, 82: 423-435.

Koruyan, K., Deliormanli, A.H., Karaca, Z., Momayez, M., Lu, H. \& Yalçin, E. (2012). Remote sensing in management of mining land and proximate habitat. The Journal of the Southern African Institute of Mining and Metallurgy, 112: 667-672.

Kováŕ, P. (1979). Geobotanické aspekty rekultivace odkališt' manganorudných a kyzových závodů Chvaletice [Geobotanical aspects of the sedimentation pond reclamation after pyrite processing near surface mining at Chvaletice]. Práce a Studie, 11:63-78 [in Czech].

Kováŕ, P. (1982). Rostliny na odkalištích [Plants of sedimentation ponds]. Živa, 30:124 [in Czech].

Kováŕ, P. (Ed.) (2004). Natural Recovery of Human-Made Deposits in Landscape (Biotic Interactions and Ore/Ash-Slag Artificial Ecosystems). Academia, Prague.

Kovář, P., Štefánek, M. \& Mrázek, J. (2011). Responses of vegetation stages with woody dominants to stress and disturbance during succession on abandoned tailings in cultural landscape. Journal of Landscape Ecology, 4(2): 35-48.

Mineral commodity summaries of the Czech Republic: statistical data to 2013 (2013). Prague: Ministry of Environment of the Czech Republic, $311 \mathrm{p}$.

Novák, J. \& Prach, K. (2003). Vegetation succession in basalt quarries: Pattern on a landscape scale. Applied Vegetation Science, 6:111-116.

Novák, J. \& Prach, K. (2010). Artificial sowing of endangered dry grassland species into disused basalt quarries. Flora 205 (3): 179-183.

Prach, K. (1982). Vegetace na substrátech vzniklých těžbou nerostných surovin. [Vegetation on substrates created by mining]. Acta ecologica nature ac regionis, 1982:49-50 [in Czech].

Prach, K. (1987). Succession of vegetation on dumps from strip coal mining N.W. Bohemia, Czechoslovakia. Folia Geobotanica et Phytotaxonomica, 22(4): 339-354.

Prach, K. (2012). Coal mining spoil heaps in the Most region: restoration potential of spontaneous succession. In: Jongepierová, I., Pešout, P., Jongepier, J.W. \& Prach, K. (eds.) Ecological restoration in the Czech Republic. Nature Conservation Agency of the Czech 
Republic (pp 97-98), Prague.

Prach, K. \& Hobbs, R. J. (2008). Spontaneous succession versus technical reclamation in the restoration of disturbed sites. Restoration Ecology, 16: 363-366.

Prach, K. \& Pyšek, P. (1994). Spontaneous establishment of woody plants in central European derelict sites and their potential for reclamation. Restoration Ecology, 2: 190-197.

Prach K., Pyšek P. \& Bastl M. (2001). Spontaneous vegetation succession in human-disturbed habitats: A pattern across seres. Applied Vegetation Science, 4: 83-88.

Prach, K., Řehounková, k., Lencová, K., Jírová, A., Konvalinková, P., Mudrák, O., Študent, V., Vaněček, Z., Tichý, L., Petř́k, P., Šmilauer, P. \& Pyšek, P. (2014). Vegetation succession in restoration of disturbed sites in Central Europe: the direction of succession and species richness across 19 seres. Applied Vegetation Science, 17: 193-200.

Rebele, F. (2013). Differential succession towards woodland along a nutrient gradient. Applied Vegetation Science, 16 (3): 365-378.

Romportl, D., Chuman, T. \& Lipský, Z. (2013). Landscape typology of Czechia. Geografie, 118 (1): 16-39.

Řehoř, M. \& Ondráček, V. (2009). Methodology of Restoration Research in Czech Republic. World Academy of Science, Engineering and Technology, 3(8): 257-261.

Řehounková, K. \& Prach, K. (2006). Spontaneous vegetation succession in disused gravel-sand pits: role of local site and landscape factors. Journal of Vegetation Science, 17: 493-500.

Řehounková, K., Řehounek, J. \& Prach, K. (eds.) (2011). Near-natural restoration vs. technical reclamation of mining sites in the Czech Republic. University of South Bohemia in České Budějovice, České Budějovice.

Řehounková, K. \& Prach, K. (2008). Spontaneous vegetation succession in gravel-sand pits: a potential for restoration. Restoration Ecology, 16: 305-312.

Sádlo, J. \& Tichý, L. (2002). Sanace a rekultivace po lomové a důlní těžbě: tržné rány v krajině a jakje léčit. [Reclamation of quarries and mines: disturbed sites in the landscape and how to restore them]. ZO ČSOP Pozemkový spolek Hády, Brno.

Sádlo, J. (1983). Vegetace vápencových lomů Českého krasu. [Vegetation of limestone quarries in the Bohemian Karst region]. Diploma thesis, Faculty of Science, Charles University in Prague, [in Czech].

Schulz, F. \& Wiegleb, G. (2000). Development options of natural habitats in a post-mining landscape. Land Degradation and Development, 11:99-110.

The State Mining Administration (2015). The State Mining Administration - History. [online]. Retrieved November 3, 2015, from http://cbusbs.cz/index.php/2011-07-28-1814-23.html

Tichý, L. (2006). Diverzita vápencových lomů a možnosti jejich rekultivace s využitím přirozené sukcese na př́kladu Růženina lomu. [Diversity of limestone quarries and possibilities of their reclamation with using natural succession on example of 'Růženin lom' quarry]. Zprávy České Botanické Společnosti, 41(Mater. 21): 89-103 [in Czech].

Tichý, L. (2012). Restoration of dry grassland vegetation in the abandoned Hády limestone quarry near Brno. In: Jongepierová, I., Pešout, P., Jongepier, J.W. \& Prach, K. (eds.) Ecological restoration in the Czech Republic (pp 102-103). Nature Conservation Agency of the Czech Republic, Prague. 
Chuman T.: Restoration practices used on post mining sites and industrial deposits in the Czech Republic with an example of natural restoration of granodiorite quarries and spoil heaps

Tichý, L. \& Donocik, R. (2012). Experimental restoration of species-rich deciduous forest on mining deposits in Mokrá limestone quarry. In: Jongepierová, I., Pešout, P., Jongepier, J.W., Prach, K. (eds.) Ecological restoration in the Czech Republic (pp 104-105). Nature Conservation Agency of the Czech Republic, Prague.

Tolasz, R., Míková, T., Valeriánová, A. \& Voženílek, V. (Eds.), (2007). Climate Atlas of Czechia. Czech Hydrometeorological Institute, Prague.

Treml,V., Wild, J., Chuman,T. \& Potůčková, M. (2011). Assessing the change in cover of non-indigenous dwarf-pine using aerial photographs, a case study from The Hrubý Jeseník Mts., The Sudetes. Journal of Landscape Ecology, 4(2): 90 - 104.

Trnková, R., Řehounková, K. \& Prach, K. (2010). Spontaneous succession of vegetation on acidic bedrock in quarries in the Czech Republic. Preslia, 82: 333-343.

Tropek, R., Kadlec, T., Hejda, M., Kočárek, P., Skuhrovec, J., Malenovský, I., Vodka, Š., Spitzer, L., Baňař, P. \& Konvička, M. (2012).Technical reclamations are wasting the conservation potential of post-mining sites. A case study of black coal spoil dumps. Ecological Engineering, 43: 13-18.

Tropek, R., Kadlec, T., Karesova, P., Spitzer, L., Kocarek, P., Malenovsky, I., Banar, P., Tuf, I.H., Hejda, M. \& Konvicka, M. (2010). Spontaneous succession in limestone quarries as an effective restoration tool for endangered arthropods and plants. Journal of Applied Ecology, 47 (1): 139-147.

Tropek, R. \& Konvička, M. (2008). Can quarries supplement rare xeric habitats in a piedmont region? Spiders of the Blansky Les MTS. Czech Republic. Land Degradation and Development, 17(1):101-114.

Tropek, R. \& Prach, K. (2012). Mining and post-industrial sites. In: Jongepierová, I., Pešout, P., Jongepier, J.W. \& Prach, K. (eds.) Ecological restoration in the Czech Republic (pp 87-93). Nature Conservation Agency of the Czech Republic, Prague.

Turner, I. M., Wong, Y. K., Chew, P. T. \& Ibrahim, A. B. (1996). Rapid assessment of tropical rain forest successional status using aerial photographs. Biological Conservation, 77:177-183.

van Swaay, C. A. M. (2002). The importance of calcareous grasslands for butterflies in Europe. Biological Conservation, 104 (3): 315-318.

Vrbová, M. \& Štýs, S. (2008). 60 years of land reclamation after opencast coal mining - a success story of Czech reclamation work. Metal Mine 10: 23-27.

Walker, L.R. \& del Moral, R. (2003). Primary succession and ecosystem rehabilitation. Cambridge University Press, Cambridge, UK.

Wiegleb, G. \& Felinks, B. (2001). Primary succession in post-mining landscapes of Lower Lusatia - chance and necessity. Ecological Engineering, 17:199-217.

Zobel, M., van der Maarel, E. \& Dupré, C. (1998). Species pool: the concepts, its determination and significance for community restoration. Applied Vegetation Science, 1, 55-56. 